\title{
Diversity and structure preferences for ant-hemipteran mutualisms in cocoa trees (Theobroma cacao L., Sterculiaceae)
}

Diversidade e preferências estruturais para o mutualismo entre formigas e hemípteros em cacaueiros (Theobroma cacao L., Sterculiaceae)

\author{
Elmo B. A. Koch (1) | Thamy E. D. Marques' (1) | Cléa S. F. Mariano" (1) | Esperidião A. S. Neto, "I (D) \\ Alexandre Arnhold", III (D) Ana L. B. G. Peronti ${ }^{i v}$ (D) | Jacques H. C. Delabie ", "I \\ 'Comissão Executiva do Plano da Lavoura Cacaueira. Ilhéus, Bahia, Brasil \\ "Universidade Estadual de Santa Cruz. Ilhéus, Bahia, Brasil \\ I"Universidade Federal do Sul da Bahia. Ilhéus, Bahia, Brasil \\ Iv Universidade Estadual Paulista Júlio de Mesquita Filho. Jaboticabal, São Paulo, Brasil
}

\begin{abstract}
The aim of this study is to evaluate the diversity and specificity of ant-hemipteran mutualisms according to the different structures observed on cocoa trees. The experiment was carried out in two cocoa planting systems: cabruca and derruba total at Ilhéus, Brazil. We made observations and collected monthly over one year the mutualistic ants and hemipterans that occurred on Theobroma cacao L. trees. Observations were performed on cacao trees at three distinct sites of the plant: flowers, pods and leaf flush. We observed 932 ant-hemipteran associations, comprising 203 different mutualistic interactions. The assemblage was composed of 26 hemipteran species and 54 ant species. No differences were observed in the ant community, however, we found differences in the hemipteran community according to the different structure evaluated. We recorded a total of 404 trophobiosis events on pods, 394 on leaf flushes and 134 on flowers. Our results point out the diversity of ant-hemipteran trophobioses in the cocoa agrosystems resembles the diversity found in tropical forests and demonstrate that the location of interactions may result in ecological restrictions for some organisms involved in these trophobioses in cacao agrosystems.
\end{abstract}

Keywords: Formicidae. Hemiptera. Trophobioses. Theobroma cacao. Insect-insect relationships.

Resumo: O objetivo deste estudo foi avaliar a diversidade e a especificidade dos mutualismos formigas-hemípteros, de acordo com as diferentes estruturas observadas nas árvores de cacau. $\bigcirc$ experimento foi realizado em dois sistemas de plantio de cacau: 'cabruca' e 'derruba total', em Ilhéus, Brasil. Fizemos observações e coletamos mensalmente, ao longo de um ano, as formigas e os hemípteros em interações mutualísticas em árvores de Theobroma cacao L. As observações foram realizadas em três locais distintos da planta: flores, frutos e lançamentos. Observamos 932 associações entre formigas-hemípteros, compreendendo 203 diferentes interações mutualísticas. Registramos 26 espécies de hemípteros e 54 de formigas. Não observamos diferenças na comunidade de formigas, no entanto, observamos diferença para a comunidade de hemípteros, de acordo com as diferentes estruturas avaliadas. Registramos total de 404 eventos de trofobiose em frutos, 394 em lançamentos e 134 em flores. Nossos resultados apontam que a diversidade de trofobioses nos agrossistemas cacaueiros se assemelha à diversidade encontrada em florestas tropicais, demonstrando que a localização das interações pode resultar em restrições ecológicas para alguns organismos envolvidos nessas trofobioses nos agrossistemas cacaueiros estudados.

Palavras-chave: Formicidae. Hemiptera. Trofobioses. Theobroma cacao. Relações inseto-inseto.

KOCH, E. B. A., T. E. D. MARQues, C. S. F. MARIANO, E. A. S. NETO, A. ARNHOLD, A. L. B. G. PERONTI \& J. H. C. DELABIE, 2020. Diversity and structure preferences for ant-hemipteran mutualisms in cocoa trees (Theobroma cacao L., Sterculiaceae). Boletim do Museu Paraense Emílio Goeldi. Ciências Naturais 15(1): 65-81. DOI: http://doi.org/10.46357/bcnaturais.v15i1.251.

Autor para correspondência: Elmo B. A. Koch. Comissão Executiva do Plano da Lavoura Cacaueira. Laboratório de Mirmecologia. Rodovia Ilhéus-Itabuna, km 22. Ilhéus, BA, Brasil. CEP 45600-970 (elmoborges@gmail.com).

Recebido em 22/12/2019

Aprovado em 20/02/2020

Responsabilidade editorial: Rony Peterson Santos Almeida
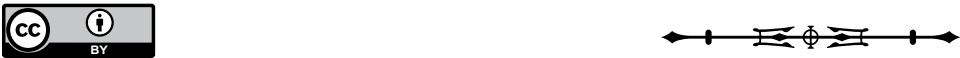


\section{INTRODUCTION}

Mutualistic interactions between ants and hemipteran are classified as trophobioses (the relationship in which one species feeds on the other's excretions while provides protection) and are observed in a wide range of host plants and environments, both in natural and agricultural ecosystems (Delabie, 2001; Rico-Gray \& Oliveira, 2007). These interactions have been widely studied (Way, 1963; Buckley, 1987; Rico-Gray \& Oliveira, 2007; Stadler \& Dixon, 2008; Canedo-Júnior et al., 2019; Marques et al., 2018), and most of them are facultative (Rico-Gray \& Oliveira, 2007). Ants feed on the excretion of hemipterans, an important sugary resource called honeydew (Way, 1963; Delabie, 2001). This corresponds to the host plant sap metabolized in the digestive tract of the hemipteran partner (Buckley, 1987). The 'honeydew' is a relatively predictable resource and composed of essential nutrients such as amino acids and carbohydrates and, therefore, can sustain high diversity and biomass of arboreal ants (Blüthgen et al., 2000). In contrast, hemipterans are protected from their natural enemies by ants (Way, 1963; Buckley, 1987). In addition, ants remove excess honeydew to prevent fumagine and help hemipterans to disperse on new host plants (Fowler et al., 1991; Delabie et al., 1994). Thus, the ants indirectly contribute to increase the abundance and distribution of hemipterans to get 'honeydew'.

Ant trophobioses usually involve certain costs, such as physiological and developmental constraints, as well as benefits for trophobionts, such as enemy clearance and greater reproductive success (Stadler \& Dixon, 2008; Hölldobler \& Wilson, 1990). The outcome of different interspecific associations may vary according to the ecological context in which species are involved (Bronstein, 1994; Del-Claro \& Oliveira, 2000; Rico-Gray \& Oliveira, 2007). Understanding how these conditionality factors that is, which may influence and thus condition the outcome of mutualistic interactions - has been the goal and challenge of many studies (Cushman \& Whitham, 1989; Bronstein, 1994; Chamberlain et al., 2014; Koch et al., 2016).
Studies have pointed ant-hemipteran associations to be beneficial to the plant (Eubanks \& Styrsky, 2006; Styrsky \& Eubanks, 2006). Ants that participate in this type of interactions may be effective for biological control in agricultural systems (Khoo \& Ho, 1992; Vandermeer et al., 2002; Eubanks \& Styrsky, 2006; Perfecto \& Vandermeer, 2006; Jha et al., 2012), since, while defending the source of honeydew, they may reduce the activity of other allegedly harmful herbivores thus contributing for the 'fitness' of the host plants (Vandermeer et al., 2002). In contrast, at high densities, associated ants can also potentiate the deleterious effects of hemipterans such as reducing growth, flowering and fruiting of host plants (Buckley, 1987).

Tropical perennial crops, such as cacao tree (Theobroma cacao L., Malvaceae), exemplify agricultural systems in which there is a wide and complex range of interactions between ants and hemipteran (Delabie, 2001; Delabie et al., 2007). As in other ecosystems, the distribution of ants and hemipteran in the cocoa agrosystem may not be random, as ants may associate with hemipteran that produce better quality and larger amounts of honeydew (Bristow, 1991) and hemipterans can be found on specific host plants or parts of them (Cushman \& Addicott, 1991). In general, the interactions described can be observed on the stem or the body of flowers and pods, or during cacao leaf flush (Bondar, 1939). The aim of this study was to evaluate the diversity and specificity of ant-hemipteran mutualistic interactions according to the structures of the cocoa trees.

\section{MATERIAL AND METHODS}

\section{STUDY AREA}

The study was carried out in two different cocoa planting systems (Theobroma cacao L., Malvaceae): cabruca and derruba total (Schroth et al., 2011) at llhéus, Brazil. In the cabruca system, the forest understory is removed for the implantation of cacao trees, and the planting area is shaded by native Atlantic Forest trees. In this system were 
studied three areas, located (one in each) on the farms: São Francisco (14 45' 04" S; $39^{\circ}$ 13' 11' W), Primavera (14 47' 34" S; $39^{\circ} 12^{\prime} 44^{\prime \prime}$ W) and Nossa Senhora da Vitória (14 45' 55" S; $39^{\circ} 12^{\prime}$ 07" W). The distance between the areas was at least two kilometers. In the derruba total system, the three studied areas have monospecific shading, generally by species of Erythrina sp. (Leguminosae) and the cocoa trees are planted at intervals of three meters. In this system can also be found some fruit trees such as jackfruit (Artocarpus integrifolia L. f., Moraceae). The three areas studied in this system are located in the experimental areas of the Cocoa Research Center (CEPLAC) (headquarters: $14^{\circ} 45^{\prime} \mathrm{S} ; 39^{\circ} 13^{\prime} \mathrm{W}$ ). The distance between the areas was up to 600 meters.

\section{SAMPLING OF ANT-HEMIPTERAN INTERACTIONS}

We chose randomly three plots of $50 \times 25 \mathrm{~m}$ per site, totaling six study areas. The number of trees per plot ranged from 116 to 163 . We made observations monthly throughout 2014, and collected the ant and hemipteran species that occurred in mutualistic interactions on all $T$. cacao trees within the plots. Observations in each cacao tree were performed for five minutes on each following structure: flowers, pods and leaf flush, where these interactions are observed more frequently (Figure 1).

\section{SPECIES IDENTIFICATION}

The ant specimens were identified in species or morphospecies level by comparison with the reference collection of the Laboratory of Myrmecology at CEPEC/ CEPLAC. Hemipteran specimens were identified to species or genus level by experts (Dr. Ana Lúcia Benfatti Gonzalez Peronti and Dr. Olivia Evangelista). However, in many cases, especially when dealing with immatures, specimens of the Membracidae family could not be identified up to species or genus level and were therefore put together into the 'Membracidae group' for data analysis.

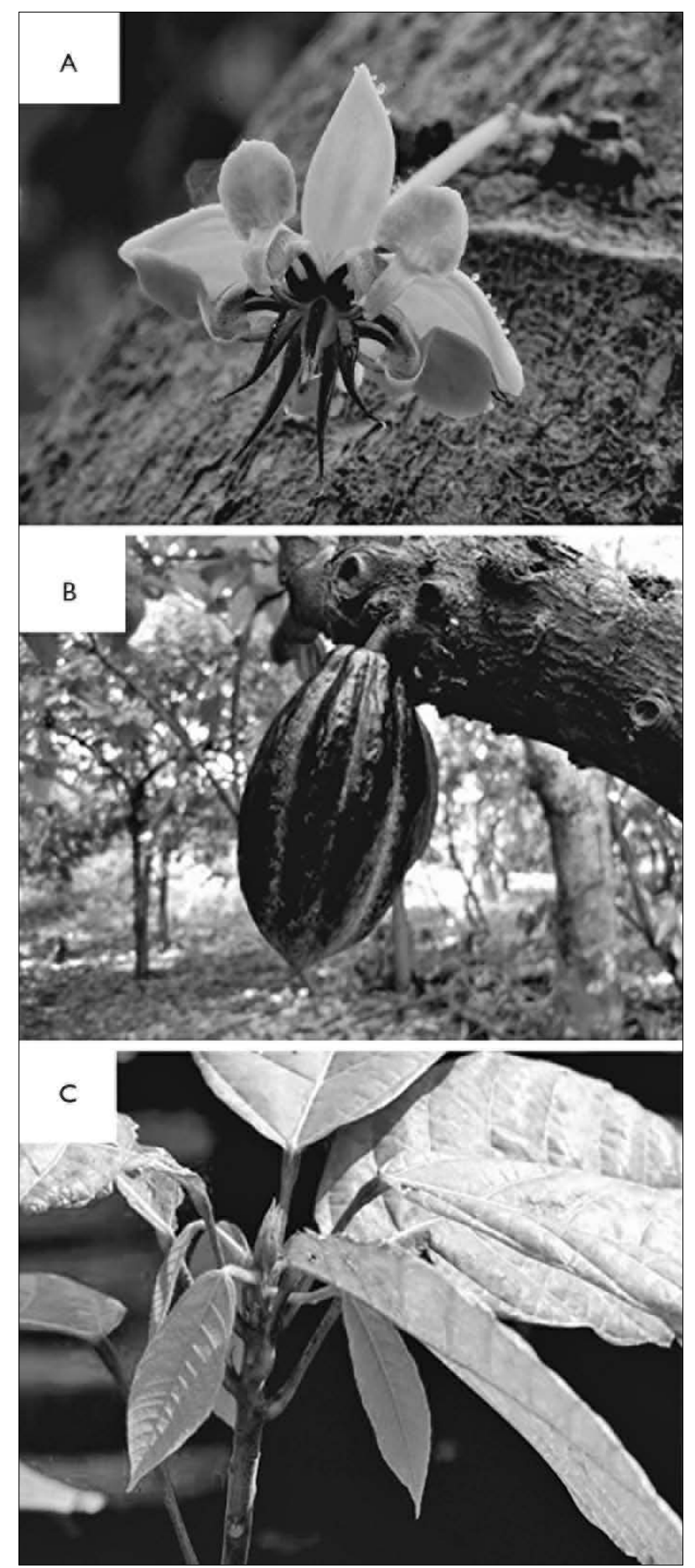

Figure 1. Representative figures of the different structures where mutualistic interactions between ants and hemiptera were observed in Theobroma cacao L. (Malvaceae): A) flowers; B) pod; C) leaf flush. Photos: Elmo B. A. Koch (2018).

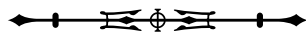




\section{DATA ANALYSIS}

There was no separation of species and interactions between environments for data analysis, since the purpose of the study was to obtain a general overview of interactions and occurrence sites in the agrosystems. To check the number and diversity of interactions between different species as well as the occurrence ratios of interactions as well the local observed in the plant a matrix of the records of the observed interactions was built.

We used the Shannon-Weaner diversity index $\left(\mathrm{H}^{\prime}\right)$ and Jaccard and Bray-Curtis similarity indexes, respectively, to compare the interactions between hemipteran and ants, regarding diversity and similarity, according to the structure observed on the plant (flower, pod and leaf flush). We used one-way ANOVAs to test the differences in mean values of ant richness, hemipterans richness and trophobioses richness - pairs of interacting species according to the structure observed on the plant (flower, pod and leaf flush), followed by Tukey's post hoc test. To assess the specificity of mutualistic ant-hemipteran interactions according to the structures of the cocoa trees, we performed a Permutational Multivariate Analysis of Variance (PERMANOVA, Anderson, 2001). In this analysis, the frequency of occurrence of each interaction per plot was the response variable, while the predictor variable was the structure of the occurrence (flowers, pods and leaf flush). Statistical significance was obtained by comparisons with a null model (4,999 permutations of the original matrix). All analyzes were performed using $R$ v. 3.5.0 (R Development Core Team, 2018) using vegan 2.3-4 package (Oksanen et al., 2015).

\section{RESULTS}

\section{HEMIPTERAN AND ANT SPECIES ASSOCIATED WITH Theobroma cacao}

We observed 932 mutualistic interaction records of hemipterans and ants on Theobroma cacao, comprising 203 different types of interactions. The hemipteran assemblage interacting with ants was composed of 26 species belonging to four families (Aphididae, Coccidae, Membracidae and Pseudococcidae). In turn, the ants belonged to 54 species in 16 genera and six subfamilies (Appendix). The commonest interactions in the whole study were between the hemipterans Horiola picta (Coquebert, 1801), Anobilia sp.1, Planococcus minor (Maskell, 1897) and Toxoptera aurantii (Boyer de Fonscolombe, 1841) and the ants Dolichoderus bispinosus (Olivier, 1792), Dolichoderus bidens (Linnaeus, 1758), Azteca chartifex spiriti Forel, 1912, Solenopsis geminata (Fabricius, 1804), Ectatomma tuberculatum (Olivier, 1792) and Wasmannia auropunctata (Roger, 1863) (Appendix).

We found a total of 12 species of hemipterans on flowers, 24 on pods and 23 on leaf flush. The Membracidae Neotynelia nigra (Funkhouser, 1940) was found exclusively on leaf flush, while Fulgoromorpha sp. and Nipaecoccus sp. (Membracidae) occurred only on pods. None hemipteran was exclusive to the flowers (Appendix).

We found a total of 28 ant species on flowers, 34 on pods and 45 on leaf flush. We recorded three species occurring exclusively on the flower: Camponotus textor Forel, 1899, Nylanderia fulva (Mayr, 1862) and Nylanderia sp.2; four on pods: Azteca paraensis bondari Forel, 1904, Crematogaster sp.3, Pheidole sp.1 (group Fallax) and Tetramorium simillimum Smith, 1851. Among the whole 54 ant species observed, 15 (27.8\%) occurred exclusively on leaf flush (Appendix). Among these stands out the most species of the genus Pheidole $(n=5)$, in addition to a single species of Brachymyrmex - Brachymyrmex admotus Mayr, 1887 - and Pseudomyrmex - Pseudomyrmex gracilis (Fabricius, 1804).

We found, on average, a greater ant richness on leaf flushes (mean \pm SD: $13.33 \pm 4.22$ ), followed by pods (12 \pm 3.41$)$ and flowers $(9.33 \pm 4.18)$. However, these differences were not statistically significant $\left(F_{2,15}=\right.$ 1.591; $P=0.237$; Figure 2A). Regarding the number of hemipterans, we found a significant difference according to the structure observed on the tree $\left(F_{2,15}=13.47\right.$; $P<0.001$; Figure 2B). We found, on average, fewer 
hemipterans on the flowers $(4.67 \pm 2.07)$, which was significantly different $(<0.05)$ from the number of hemipterans found on pods (mean \pm SD: $11 \pm 2.97$ ) and leaf flush (10.5 \pm 1.87 ) (Figure 2B). No differences were observed in the ant community composition according to the observation places on the plant (Jaccard: $F_{2,15}=0.854$; $P=0.7244$; Bray-Curtis: $F_{2,15}=0.855 ; P=0.635$; Figure $3 \mathrm{~A})$. However, we found differences in the hemipteran community (Jaccard: $F_{2,15}=3.965 ; P<0.001$; BrayCurtis: $F_{2,15}=6.179 ; P<0.001$; Figure 3B). According to the Tukey's honestly significant differenc (HSD) test of multiple comparisons, each structure presents an assemblage of hemipterans significantly different from the other $(P<0.005)$.

\section{ANT-HEMIPTERAN INTERACTIONS ACCORDING TO THE STRUCTURES OF THE COCOA TREES}

We recorded a total of 404 trophobiotic interactions on pods, 394 on leaf flushes and 134 on flowers. We found significant differences in the number of trophobioses according to the structure of the tree $\left(F_{2,15}=6.473 ; P=\right.$ 0.009 ; Figure $2 \mathrm{~B})$. The number of interactions observed on flowers (mean $\pm \mathrm{SD}: 22.3 \pm 10.1$ ) was significantly less $(<0.05)$ than the number of interactions on pods $(67.3 \pm 18.1)$ and leaf flushes $(66.2 \pm 37.4)$ (Figure 4A). We did find a significant difference in the ant-hemipteran pairs in interaction according to the structure observed on the tree $\left(F_{2,15}=10.36 ; P=0.0014\right.$; Figure 4B). The value observed on flowers (mean \pm SD: $13.3 \pm 6.12$ ), was significantly different $(<0.05)$ than on other structures (leaf flushes $=27.66 \pm 7.11$; pods $=29.3 \pm 6.8)$ (Figure 3B). The diversity of interactions was higher on pods $\left(\mathrm{H}^{\prime}=\right.$ 4.30), followed by leaf flushes $\left(H^{\prime}=4.23\right)$ and flowers $\left(H^{\prime}=3.65\right)$. We found no difference in the composition of interactions (different pairs in interaction) according to the different structures observed on the cocoa trees (Jaccard: $F_{2,15}=1.056 ; P=0.304$; Bray-Curtis: $F_{2,15}=$ 1.148; $P=0.224)$.

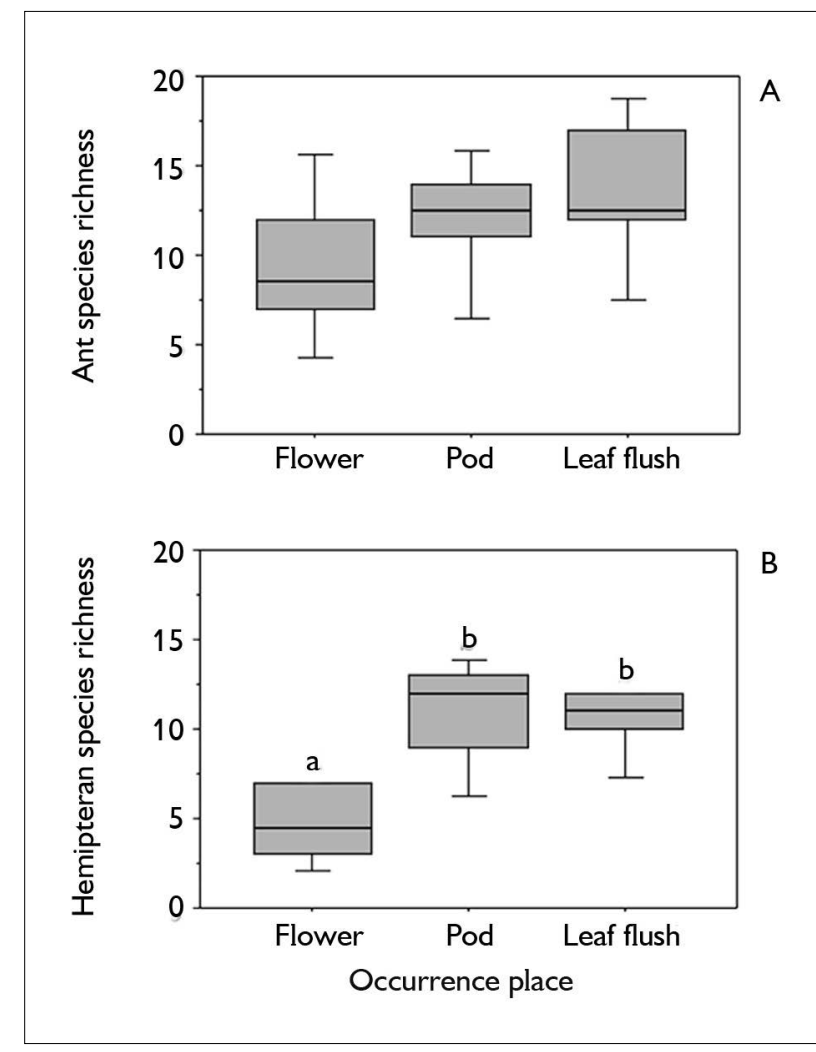

Figure 2. Specific richness of ants (A) and hemipteran (B) according to structure observed (occurrence place) in Theobroma cacao L. (Malvaceae). Different letter indicates significant differences between the means.

We observed 57 unique interactions on leaf flushes and 58 on T. cacao pods. No interaction was observed occurring exclusively on the flowers. The interactions that were most frequently recorded on flowers were between the hemipteran Toxoptera aurantii and the ants Linepithema neotropicum Wild, 2007 ( $\mathrm{n}=10)$, Dolichoderus bispinosus (9), Dolichoderus bidens (8), Crematogaster acuta (Fabricius, 1804) (8), Azteca chartifex spiriti (7) and Solenopsis geminata (7). Among the most frequent interactions throughout the study, this observation site stands out Planococcus minor and Tropidoscyta sp.2 that were found interacting, respectively, with a single or two species of ants on the flowers (Table 1).

On the pods, the commonest interactions were between the hemipteran Anobilia sp.1 and the ants 

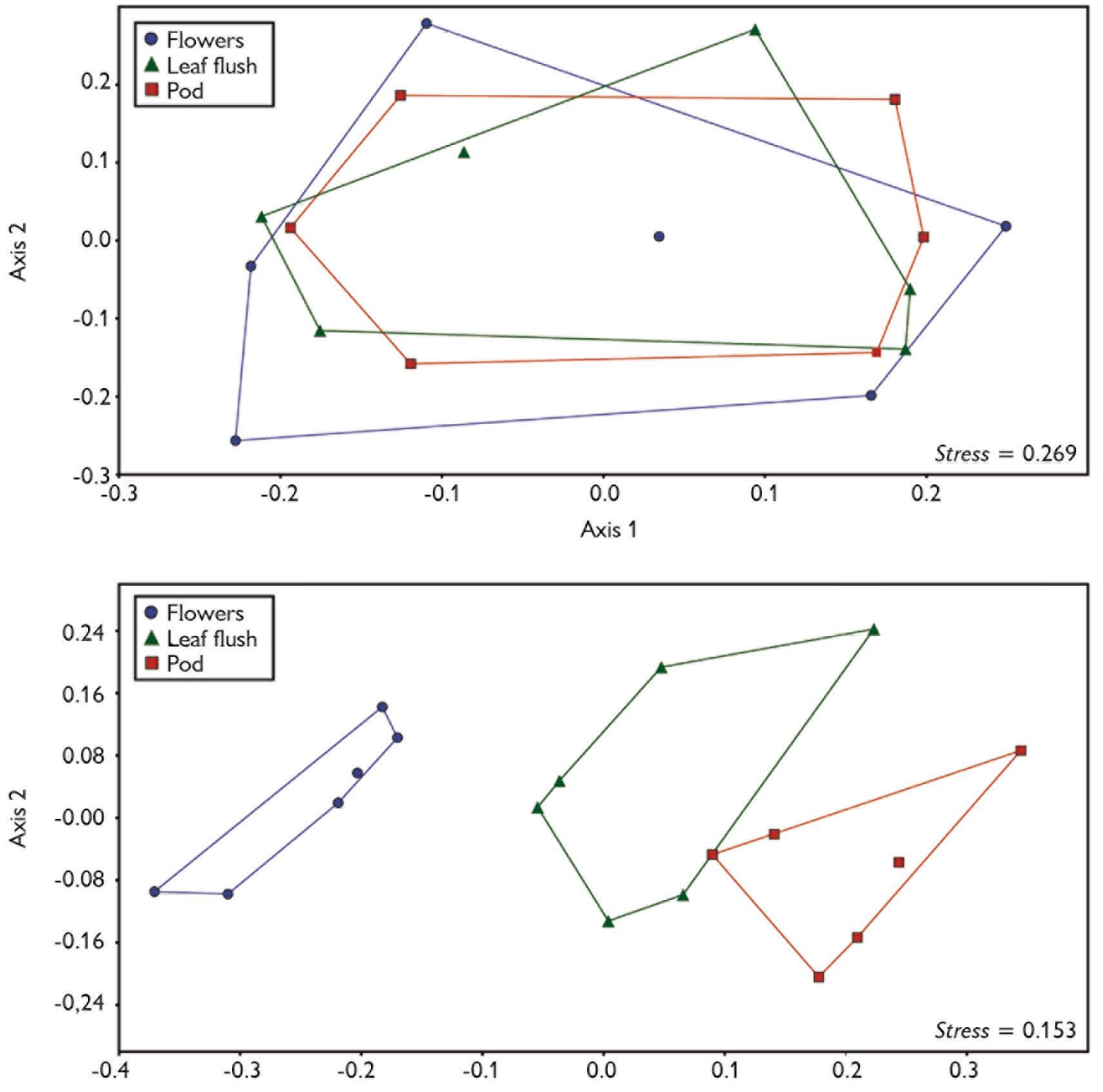

Axis 1

Figure 3. Non-metric multidimensional scaling (NMDS) of (A) ant and (B) hemiptera assemblages, separated according to different structure observed on cocoa trees.

D. bidens (25) and $A$. chartifex spiriti (18); between P. minor and the ants $A$. chartifex (17), W. auropunctata (17) and $E$. tuberculatum (13 records); and between Horiola picta and the ants $A$. chartifex spiriti (16) and D. bispinosus (15). The interactions involving $H$. picta and C. acuta (7), just like between Tragopa sp.2 and D. bispinosus (6), were found exclusively on pods. Among the most frequent interactions seen throughout the study, T. aurantii was recorded interacting with eight of the nine most frequently recorded ant species (except $W$. auropunctata, observed interacting with P. minor only). Moreover, stands out in this place of observation, the interactions between Anobilia sp.1 and D. bidens (Table 1).

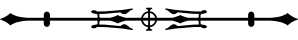


Table 1. Ant-hemipteran observed interactions (considering the 20 most frequent interactions throughout the study) according to structure observed: flowers, pod and leaf flush in Theobroma cacao L. (Malvaceae).

\begin{tabular}{|c|c|c|c|c|c|c|c|}
\hline \multicolumn{8}{|c|}{ Flowers in Theobroma cacao L. (Malvaceae) } \\
\hline $\begin{array}{c}\text { Tropidoscyta } \\
\text { sp.2 }\end{array}$ & $\begin{array}{c}\text { Membracidae } \\
\text { sp. }\end{array}$ & $\begin{array}{c}\text { Tragopa } \\
\text { auriculata }\end{array}$ & $\begin{array}{c}\text { Horiola } \\
\text { picta }\end{array}$ & $\begin{array}{c}\text { Anobilia } \\
\text { sp.1 }\end{array}$ & $\begin{array}{c}\text { Planococcus } \\
\text { minor }\end{array}$ & $\begin{array}{l}\text { Toxoptera } \\
\text { aurantii }\end{array}$ & Figure $1 \mathrm{~A}$ \\
\hline- & - & - & - & - & - & 7 & Solenopsis geminata \\
\hline- & - & - & - & - & 3 & 5 & Ectatomma tuberculatum \\
\hline- & - & - & - & - & - & 9 & Dolichoderus bispinosus \\
\hline- & - & - & - & - & - & 8 & Crematogaster acuta \\
\hline- & - & - & - & - & 1 & 7 & Azteca chartifex \\
\hline- & - & - & - & - & - & 10 & Linepithema neotropicum \\
\hline 1 & - & - & - & - & - & 8 & Dolichoderus bidens \\
\hline- & - & - & - & - & - & 6 & Monomorium floricola \\
\hline- & - & - & - & - & - & 3 & Wasmannia auropunctata \\
\hline \multicolumn{8}{|c|}{ Pod in Theobroma cacao L. (Malvaceae) } \\
\hline $\begin{array}{c}\text { Tropidoscyta } \\
\text { sp.2 }\end{array}$ & $\begin{array}{c}\text { Membracidae } \\
\text { sp. }\end{array}$ & $\begin{array}{c}\text { Tragopa } \\
\text { auriculata }\end{array}$ & $\begin{array}{l}\text { Horiola } \\
\text { picta }\end{array}$ & $\begin{array}{c}\text { Anobilia } \\
\text { sp.1 }\end{array}$ & $\begin{array}{c}\text { Planococcus } \\
\text { minor }\end{array}$ & $\begin{array}{l}\text { Toxoptera } \\
\text { aurantii }\end{array}$ & Figure 1B \\
\hline- & - & - & - & - & 12 & 4 & Solenopsis geminata \\
\hline- & - & - & - & - & 13 & 9 & Ectatomma tuberculatum \\
\hline- & 4 & 2 & 15 & - & - & 2 & Dolichoderus bispinosus \\
\hline- & - & - & - & - & - & 5 & Crematogaster acuta \\
\hline- & - & - & 16 & 18 & 17 & 4 & Azteca chartifex \\
\hline- & - & - & - & - & - & 1 & Linepithema neotropicum \\
\hline- & - & - & - & 25 & - & 1 & Dolichoderus bidens \\
\hline- & - & - & - & - & - & 1 & Monomorium floricola \\
\hline- & - & - & - & - & 17 & - & Wasmannia auropunctata \\
\hline \multicolumn{8}{|c|}{ Leaf flush in Theobroma cacao L. (Malvaceae) } \\
\hline $\begin{array}{c}\text { Tropidoscyta } \\
\text { sp.2 }\end{array}$ & $\begin{array}{c}\text { Membracidae } \\
\text { sp. }\end{array}$ & $\begin{array}{l}\text { Tragopa } \\
\text { auriculata }\end{array}$ & $\begin{array}{l}\text { Horiola } \\
\text { picta }\end{array}$ & $\begin{array}{c}\text { Anobilia } \\
\text { sp.1 }\end{array}$ & $\begin{array}{c}\text { Planococcus } \\
\text { minor }\end{array}$ & $\begin{array}{l}\text { Toxoptera } \\
\text { aurantii }\end{array}$ & Figure $1 C$ \\
\hline- & - & - & - & - & 10 & 18 & Solenopsis geminata \\
\hline- & - & - & - & - & 3 & 14 & Ectatomma tuberculatum \\
\hline- & 15 & 15 & 23 & - & - & 16 & Dolichoderus bispinosus \\
\hline- & - & - & - & - & - & 12 & Crematogaster acuta \\
\hline- & - & - & 4 & 14 & 11 & 14 & Azteca chartifex \\
\hline- & - & - & - & - & - & 11 & Linepithema neotropicum \\
\hline 7 & - & - & - & 12 & - & 11 & Dolichoderus bidens \\
\hline- & - & - & - & - & - & 3 & Monomorium floricola \\
\hline- & - & - & - & - & 8 & 7 & Wasmannia auropunctata \\
\hline
\end{tabular}


On the leaf flushes, we recorded commonly the interactions between $H$. picta and D. bispinosus $(n=23)$, T. aurantii and the ants S. geminata (18) and D. bispinosus (17). Other interactions commonly observed were among unidentified hemipterans of the Membracidae family with D. bispinosus (30). Interactions involving $T$. aurantii and Camponotus novogranadensis Mayr, 1870 (4), as well as between Membracidae and D. bidens (5), were found exclusively on leaf flushes (Appendix). Among the commonest interactions, T. aurantii stands out at this observation site, interacting with all nine most frequently recorded ant species (Table 1). Noteworthy are also $H$. picta and T. auriculata, which were found interacting, 15 and 23 times, respectively with D. bispinosus (Table 1).

\section{DISCUSSION}

Our results show the wide diversity of ant-hemipteran trophobioses in cocoa agrosystems, rather similar to tropical forests (Blüthgen et al., 2000, 2006). The frequency and variety of interactions observed reflect the high diversity of insects and their weak specialization in this agrosystem, as pointed out by several studies (Delabie et al., 2007; Cassano et al., 2009; DaRocha et al., 2015, 2016; Canedo-Júnior et al., 2019). We found variations in the number of ant species and in the number of hemipteran species and assemblage composition in the different structure observed on cocoa tree. The ecological restrictions involved in these trophobioses for some organisms suggest that the tree location where these interactions occur is a conditionality factor of the success of the ant-hemipteran mutualisms on T. cacao.

The ants most frequently found in interaction with hemipterans were D. bidens, Cephalotes atratus (Linnaeus, 1758), A. chartifex spiriti, E. tuberculatum, D. bispinosus and $W$. auropunctata. These species include arboreal ant fauna (except $E$. tuberculatum and $W$. auropunctata, only partially arboreal) commonly found in cocoa agrosystems (Fowler et al., 1991; Delabie et al., 1994, 2007; Delabie, 2001; Marques et al., 2018). In these agrosystems, as also demonstrated in other environments, most interactions

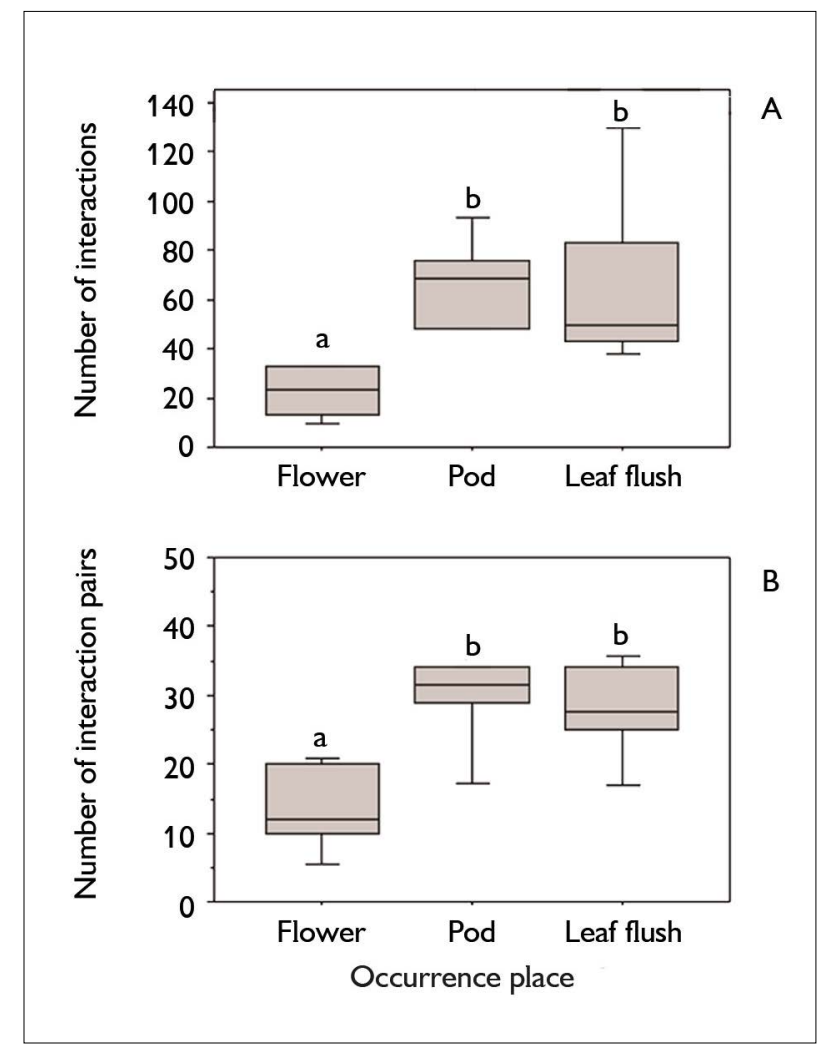

Figure 4. Number of interactions (A) and number of different anthemipteran pairs in interaction (B), according to structure observed (occurrence place) in Theobroma cacao L. (Malvaceae). Different letter indicates significant differences between the means.

occur through a small number of dominant tree ants, which monopolize most hemipterans (Bigger, 1993; Blüthgen \& Fiedler, 2004; Fagundes et al., 2016). Most of these ants contribute to constitute the mosaic of ant dominant ants which are characteristic of the Bahian cocoa plantations (Leston, 1978; Majer et al., 1994).

Most of the ants' associations were with hemipterans of the family Membracidae, which is probably related to the wide diversity of species of this group found in cacao agrosystems as well as with the easiness of immature manipulation by the ants. However, at the specific level $T$. aurantii (Aphididae) and P. minor (Pseudococcidae) were the commonest hemipterans found interacting with ants. The preference of dominant ants for certain species of hemipteran may be related to the quality of honeydew, since there is 
variation between species (Blüthgen \& Fiedler, 2004). Hemipteran species belonging to the Coccoidea superfamily (e.g. Pseudococcidae) and Aphididae, for example, excrete a nitrogen-rich honeydew (Blüthgen et al., 2003). A second possibility of this preference may be due to the especially high capacity of growth of the population of certain hemipterans (see Delabie et al., 1994 on P. minor [then called Planococcus citri Risso, 1813] interacting with $W$. auropunctata).

Although ant composition did not significantly vary among the different structures of the cocoa trees, we found significant differences in hemipterans composition. Such result may be correlated with the fact that these organisms have reduced mobility, related to the diversity of feeding strategies they present and dependence on the plants on which they occur. Hemiptera may be highly specialized for specific parts of their host plants (Bernays \& Chapman, 1994). The host plant probably affects the composition, abundance and palatability of honeydew of the Hemiptera (Bristow, 1991) and therefore can contribute to motivate the visiting ant. The honeydew is an important resource to the ants (Delabie, 2001; Blüthgen et al., 2000), which are opportunistic when choosing hemipteran to interact (Blüthgen et al., 2006), but their choices may depend on the quantity and quality of honeydew (Cushman \& Addicott, 1991). The composition of this resource comprises a wide variety of carbohydrates, lipids and amino acids. Some species of aphids, for example, may produce a higher rate of amino acids in their honeydew than others (Maltais \& Auclair, 1952).

Part of the observed interactions was highly related to the structure observed on cacao trees. We found differences in interactions of hemipterans mainly on flowers, when compared with other sites on the tree. No species of hemipteran was exclusive to the flowers, while some interactions were restricted to pods and leaf flushes. Although some species of hemipteran are often found interacting at any of the three different observation sites evaluated, the identity of the partner ant often changes with the place of interaction (Table 1). In fact, studies have shown that mutualistic interactions are strongly influenced by the environment and the ecological characteristics of where they occur (Cushman \& Addicott, 1991; Bronstein, 1994; Chamberlain et al., 2014).

Our results demonstrate that the structure of the tree where the interactions occur is conditioning the anthemipteran interactions in cacao agrosystems. However, further studies are needed to determine how our findings could be generalized, as this is the first time that the diversity of trophobiotic hemipterans is explored by considering their interactions with ants according to their location on T. cacao. New studies on the management of arboreal insects in cacao trees are necessary too, since certain ant species can effectively control a range of herbivores, especially when associated with certain hemipteran species (Vandermeer et al., 2002; Eubanks \& Styrsky, 2006; Perfecto \& Vandermeer, 2006; Jha et al., 2012). The location of occurrence (structure on tree) of ant-hemipteran interactions may represent an important conditionality factor of interactions between these insects in cacao agrosystems. A better understanding of these relationships is needed in the context of dependence of the organisms involved in these interactions.

\section{ACKNOWLEDGEMENTS}

We dedicate this study to the memories of José Abade and José Crispim Soares do Carmo, two of our tireless field assistants who recently passed away. Thanks are also due to Jose Raimundo Maia dos Santos and Gilmar Batista Costa for field support. We thank Olivia Evangelista (Commonwealth Scientific and Industrial Research Organization - CSIRO) for the Membracidae identifications. We acknowledge the project PRONEX FAPESB/CNPq PNX0011/2009 project: "Rede Multidisciplinar de Estudos sobre Formigas Poneromorfas do Brasil" which contributed with experiment funding. We also thank the Fundação de Amparo à Pesquisa do Estado da Bahia (FAPESB), Conselho Nacional de Desenvolvimento Científico e Tecnológico (CNPq), and Coordenação de 
Aperfeiçoamento de Pessoal de Nível Superior (CAPES) funding agencies for various types of scholarships.

\section{REFERENCES}

ANDERSON, M. J., 2001. A new method for non-parametric multivariate analysis of variance. Austral Ecology 26(1): 32-46. DOI: https://doi.org/10.1111/j.1442-9993.2001.01070.pp.x.

BERNAYS, E. A. \& R. F. CHAPMAN, 1994. Host plant selection by phytophagous insects. Chapman and Hall, London.

BIGGER, M., 1993. Ant-homopteran interactions in a tropical ecosystem. Description of an experiment on cocoa in Ghana. Bulletin of Entomological Research 83(4): 475-505. DOI: https:// doi.org/10.1017/S0007485300039912.

BLÜTHGEN, N., M. VERHAAGH, W. GOITÍA, K. JAFFÉ, W. MORAWETZ \& W. BARTHLOTT, 2000. How plants shape the ant community in the Amazonian rainforest canopy: the key role of extrafloral nectaries and homopteran honeydew. Oecologia 125: 229-40. DOI: https://doi.org/10.1007/s004420000449.

BLÜTHGEN, N., G. GEBAUER \& K. FIEDLER, 2003. Disentangling a rainforest food web using stable isotopes: dietary diversity in a species-rich ant community. Oecologia 137: 426-435. DOI: https:// doi.org/10.1007/s00442-003-1347-8.

BLÜTHGEN, N. \& K. FIEDLER, 2004. Preferences for sugars and amino acids and their conditionality in a diverse nectar-feeding ant community. Journal of Animal Ecology 73(1): 155-166. DOI: https:// doi.org/10.1111/j.1365-2656.2004.00789.x.

BLÜTHGEN, N., D. MEZGER \& K. E. LINSENMAIR, 2006. Anthemipteran trophobioses in a Bornean rainforest - diversity, specificity and monopolization. Insectes Sociaux 53: 194-203. DOI: https:// doi.org/10.1007/s00040-005-0858-1.

BONDAR, G., 1939. Notas entomologicas da Bahia. IV. Revista de Entomologia 10(1): 1-14.

BRISTOW, C. M., 1991. Why are so few aphids ant-tended? In: C. R. HUXLEY \& D. F. CUTLER (Ed.): Ant-plant interactions: 104-119. Oxford University Press, Oxford.

BRONSTEIN, J. L., 1994. Our current understanding of mutualism. The Quarterly Review of Biology 69(1): 31-51.

BUCKLEY, R. C., 1987. Interactions involving plants, Homoptera, and ants. Annual Review of Ecology and Systematics 18: 111-135. DOI: https://doi.org/10.1146/annurev.es.18.110187.000551.

CANEDO-JÚNIOR, E. O., A. B. MONTEIRO, A. C. M. QUEIROZ \& G. S. SILVA, 2019. Aphid-tending ants and their effects on natural enemies used in the biological control. In: B. SOUZA, L. VÁZQUEZ\& R. MARUCCI (Ed.): Natural enemies of insect pests in Neotropical agroecosystems: 523-533. Springer, Cham, Switzerland.
CASSANO, C. R., G. SCHROTH, D. FARIA, J. H. C. DELABIE \& L. BEDE, 2009. Landscape and farm scale management to enhance biodiversity conservation in the cocoa producing region of southern Bahia, Brazil. Biodiversity and Conservation 18: 577-603. DOI: https://doi.org/10.1007/s10531-008-9526-x.

CHAMBERLAIN, S. A., J. L. BRONSTEIN \& J. A. RUDGERS, 2014. How context dependent are species interactions. Ecology Letters 17(7): 881-890. DOI: https://doi.org/10.1111/ele.12279.

CUSHMAN, J. H. \& T. G. WHITHAM, 1989. Conditional mutualism in a membracid-ant association: temporal, age-specific, and densitydependent effects. Ecology 70(4): 1040-1047. DOI: https://doi. org/10.2307/1941372.

CUSHMAN, J. H. \& J. F. ADDICOTT, 1991. Conditional interactions in ant-plant-herbivore mutualisms. In: C. R. HUXLEY \& D. F. CUTLER (Ed.): Ant-plant interactions: 92-103. Oxford University Press, Oxford.

DAROCHA, W. D., S. P. RIBEIRO, F. S. NEVES, G. W. FERNANDES, M. LEPONCE \& J. H. C. DELABIE, 2015. How does bromeliad distribution structure the arboreal ant assemblage (Hymenoptera, Formicidae) on a single tree in a Brazilian Atlantic forest agroecosystem? Myrmecological News 21: 83-92.

DAROCHA, W. D., F. S. NEVES, W. DÁTTILO \& J. H. C. DELABIE, 2016. Epiphytic bromeliads as key components for maintenance of ant diversity and ant-bromeliad interactions in agroforestry system canopies. Forest Ecology and Management 372: 128-136. DOI: https://doi.org/10.1016/j.foreco.2016.04.011.

DELABIE, J. H. C., 2001. Trophobiosis between Formicidae and Hemiptera (Sternorrhyncha and Auchenorrhyncha): an overview. Neotropical Entomology 30(4): 501-516. DOI: https://doi. org/10.1590/S1519-566×2001000400001.

DELABIE, J. H. C., A. M. ENCARNAÇÃO \& C. I. MAURÍCIO, 1994. Relations between the little fire ant, Wasmannia auropunctata, and its associated mealybug, Planococcus citri, in Brazilian cocoa farms. In: D. F. WILLIAMS (Ed.): Exotic ants: biology, impact and control of introduced species: 91-103. Westview Press, Boulder, Colorado, USA.

DELABIE, J. H. C., B. JAHYNY, I. C. NASCIMENTO, C. S. F. MARIANO, S. LACAU, S. CAMPIOLO, S. M. PHILPOTT \& M. LEPONCE, 2007. Contribution of cocoa plantations to the conservation of native ants (Insecta: Hymenoptera: Formicidae) with a special emphasis on the Atlantic Forest fauna of southern Bahia, Brazil. Biodiversity and Conservation 16: 2359-2384. DOI: https://doi.org/10.1007/s10531-007-9190-6.

DEL-CLARO, K. \& P. S. OLIVEIRA, 2000. Conditional outcomes in a neotropical treehopper-ant association: temporal and species-specific variation in ant protection and homopteran fecundity. Oecologia 124: 156-165. DOI: https://doi.org/10.1007/ s004420050002. 
EUBANKS, M. D. \& J. D. STYRSKY, 2006. Ant-hemipteran mutualisms: keystone interactions that alter food web dynamics and influence plant fitness. In: J. BRODEUR \& G. BOIVIN (Ed.): Trophic and guild in biological interactions control: v. 3: 171-189. Springer, Dordrecht.

FAGUNDES, R., W. DÁTTILO, S. P. RIBEIRO, V. RICO-GRAY \& K. DEL-CLARO, 2016. Food source availability and interspecific dominance as structural mechanisms of ant-plant-hemipteran multitrophic networks. Arthropod-Plant Interactions 10: 207-220. DOI: https://doi.org/10.1007/s11829-016-9428-x.

FOWLER, H. G., L. C. FORTI, C. R. F. BRANDÃO, J. H. C. DELABIE \& H. L. VASCONCELOS, 1991. Ecologia nutricional de formigas. In: A. R. PANIZZI \& J. R. P. PARRA (Ed.): Ecologia nutricional de insetos e suas implicações no manejo de pragas: 131-223. Editora Manole/CNPq, São Paulo.

HÖLLDOBLER, B. \& E. O. WILSON, 1990. The ants: 1. ed. Belknap Press of Harvard University Press, Cambridge.

JHA, S., D. ALLEN, H. LIERE, J. VANDERMEER \& I. PERFECTO, 2012. Mutualisms and population regulation: mechanism matters. PloS ONE 7(8): e43510. DOI: https://doi.org/10.1371/journal. pone.0043510.

KHOO, K. C. \& C. T. HO, 1992. The influence of Dolichoderus thoracicus (Hymenoptera: Formicidae) on losses due to Helopeltis theivora (Heteroptera: Miridae), black pod disease, and mammalian pests in cocoa in Malaysia. Bulletin of Entomological Research 82: 485-491. DOI: https://doi.org/10.1017/S0007485300042553.

KOCH, E. B. A., F. C. CAMAROTA \& H. L. VASCONCELOS, 2016. Plant ontogeny as a conditionality factor in the protective effect of ants on a Neotropical tree. Biotropica 48(2): 198-205. DOI: https:// doi.org/10.1111/btp. 12264 .

LESTON, D., 1978. A Neotropical ant mosaic. Annals of the Entomological Society of America 71(4): 649-653. DOI: https:// doi.org/10.1093/aesa/71.4.649.

MAJER, J. D., J. H. C. DELABIE \& M. R. B. SMITH, 1994. Arboreal ant community patterns in Brazilian cocoa farms. Biotropica 26(1): 73-83. DOI: https://doi.org/10.2307/2389112.

MALTAIS, J. B. \& J. L. AUCLAIR, 1952. Occurrence of amino acids in the honeydew of the crescent-marked lily aphid, Myzus circumflexus (Buck.). Canadian Journal of Zoology 30(4): 191-193. DOI: https:// doi.org/10.1139/z52-017.
MARQUES, T. E. D., E. B. A. KOCH, I. S. SANTOS, J. R. M. SANTOS, C. S. F. MARIANO \& J. H. C. DELABIE, 2018. The diversity of ants (Hymenoptera: Formicidae) interacting with the invasive hibiscus mealybug Maconellicoccus hirsutus (Green 1908) (Hemiptera: Pseudococcidae) on ornamental and cultivated plants in Bahia, Brazil. Arthropod-Plant Interactions 12: 237-246. DOI: https://doi.org/10.1007/s11829-017-9563-z.

OKSANEN, J., R. KINDT, P. LEGENDRE, P. R. MINCHIN, R. B. O'HARA, G. L. SIMPSON, P. SOLYMOS, M. H. H. STEVENS \& H. WAGNER, 2015. The vegan package. R package version 2.3-4. Available at: https://cran.r-project.org/package=vegan. Accessed on: January 2020.

PERFECTO, I. \& J. VANDERMEER, 2006. The effect of an anthemipteran mutualism on the coffee berry borer (Hypothenemus hampei) in southern Mexico. Agriculture, Ecosystems and Environment 117(2-3): 218-221. DOI: https://doi.org/10.1016/j. agee.2006.04.007.

R DEVELOPMENT CORE TEAM, 2018. R: a language and environment for statistical computing. R Foundation for Statistical Computing, Vienna, Austria.

RICO-GRAY, V. \& P. S. OLIVEIRA, 2007. The ecology and evolution of ant - plant interactions. University of Chicago Press, Chicago.

SCHROTH, G., D. FARIA, M. ARAUJO, L. BEDE, S. A. VAN BAEL, C. R. CASSANO, L. C. OLIVEIRA \& J. H. C. DELABIE, 2011. Conservation in tropical landscape mosaics: the case of the cacao landscape of southern Bahia, Brazil. Biodiversity and Conservation 20: 1335-1354. DOI: https://doi.org/10.1007/s10531-011-0052-x.

STADLER, B. \& T. DIXON, 2008. Mutualism: ants and their insect partners. Cambridge University Press, New York, USA.

STYRSKY, J. D. \& M. D. EUBANKS, 2006. Ecological consequences of interactions between ants and honeydew-producing insects. Proceedings of the Royal Society of London Serie B 274(1607): 151-164. DOI: https://doi.org/10.1098/rspb.2006.3701.

VANDERMEER, J., I. PERFECTO, G. IBARRA NUÑEZ, S. PHILPOTT \& A. GARCIA BALLINAS, 2002. Ants (Azteca sp.) as potential biological control agents in shade coffee production in Chiapas, Mexico. Agroforestry Systems 56: 271-276. DOI: https:// doi.org/10.1023/A:1021328820123.

WAY, M. J., 1963. Mutualism between ants and honeydew producing Homoptera. Annual Review of Entomology 8: 307-344. DOI: https://doi.org/10.1146/annurev.en.08.010163.001515.

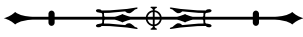


Appendix. Interactions between ants and hemipterans according to different observation sites in Theobroma cacao L. (Malvaceae). (Continue)

\begin{tabular}{|c|c|c|c|c|c|}
\hline Family/Hemipteran species & Ant species & Flower & Pod & Leaf flush & Total \\
\hline \multicolumn{6}{|l|}{ Aphididae } \\
\hline \multirow{35}{*}{$\begin{array}{l}\text { Toxoptera aurantii } \\
\text { (Boyer de Fonscolombe, 1841) }\end{array}$} & Azteca chartifex spiriti Forel, 1912 & 7 & 4 & 14 & 25 \\
\hline & Azteca instabilis (Smith, F., 1862) & & 3 & 1 & 4 \\
\hline & Azteca sp. & & & 1 & 1 \\
\hline & Camponotus (Myrmobrachys) sp. & 3 & & 1 & 4 \\
\hline & Camponotus cingulatus Mayr, 1862 & 2 & & 2 & 4 \\
\hline & Camponotus crassus Mayr, 1862 & 3 & & 3 & 6 \\
\hline & Camponotus fastigatus Roger, 1863 & 3 & 2 & 1 & 6 \\
\hline & Camponotus novogranadensis Mayr, 1870 & & & 5 & 5 \\
\hline & Camponotus textor Forel, 1899 & 1 & & & 1 \\
\hline & Camponotus trapezoideus Mayr, 1870 & & & 1 & 1 \\
\hline & Cephalotes atratus (Linnaeus, 1758) & 1 & 2 & 1 & 7 \\
\hline & Crematogaster abstinens Forel, 1899 & & & 3 & 3 \\
\hline & Crematogaster curvispinosa Mayr, 1862 & & & 1 & 1 \\
\hline & Crematogaster limata Smith, F., 1858 & 2 & 1 & 1 & 3 \\
\hline & Crematogaster acuta (Fabricius, 1804) & 8 & 5 & 12 & 25 \\
\hline & Crematogaster carinata Mayr, 1862 & & & 1 & 1 \\
\hline & Crematogaster curvispinosa & 2 & 1 & 3 & 6 \\
\hline & Crematogaster erecta Mayr, 1866 & 1 & 1 & 3 & 5 \\
\hline & Crematogaster victima Smith, F., 1858 & 3 & & & 3 \\
\hline & Crematogaster sp.1 & & & 1 & 1 \\
\hline & Crematogaster sp.2 & & & 1 & 1 \\
\hline & Dolichoderus bidens (Linnaeus, 1758) & 8 & 1 & 11 & 20 \\
\hline & Dolichoderus bispinosus (Olivier, 1792) & 9 & 2 & 16 & 27 \\
\hline & Ectatomma edentatum Roger, 1863 & 2 & & 1 & 3 \\
\hline & Ectatomma tuberculatum (Olivier, 1792) & 5 & 9 & 14 & 28 \\
\hline & Linepithema leucomelas (Emery, 1894) & & 1 & 1 & 2 \\
\hline & Linepithema neotropicum Wild, 2007 & 1 & 1 & 11 & 22 \\
\hline & Monomorium floricola (Jerdon, 1851) & 6 & 1 & 3 & 10 \\
\hline & Nylanderia fulva (Mayr, 1862) & 2 & & & 2 \\
\hline & Nylanderia sp.2 & 1 & & & 1 \\
\hline & $\begin{array}{l}\text { Odontomachus haematodus } \\
\text { (Linnaeus, 1758) }\end{array}$ & & 3 & & 3 \\
\hline & Pheidole sp.1 & 1 & 2 & 1 & 4 \\
\hline & Pheidole sp.3 & 2 & & & 2 \\
\hline & Pheidole sp.4 & & & 1 & 1 \\
\hline & Pseudomyrmex gracilis (Fabricius, 1804) & & & 1 & 1 \\
\hline
\end{tabular}

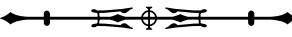


Appendix.

\begin{tabular}{c|c|c|c|c|c} 
Appendix. & \multicolumn{1}{c}{ (Continue) } \\
\hline \multirow{2}{*}{$\begin{array}{c}\text { Family/Hemipteran species } \\
\text { Toxoptera aurantii } \\
\text { (Boyer de Fonscolombe, 1841) }\end{array}$} & Ant species & Flower & Pod & Leaf flush & Total \\
\cline { 2 - 6 } & Solenopsis geminate (Fabricius, 1804) & 7 & 4 & 18 & 29 \\
\cline { 2 - 6 } & Solenopsis sp.1 & 1 & & 1 \\
\cline { 2 - 6 } & Wasmannia auropunctata (Roger, 1863) & 3 & & 1 & 1 \\
\cline { 2 - 6 } & Wasmannia rochai Forel, 1912 & & 1 & 1 \\
\hline
\end{tabular}

Coccidae

Coccus sp.

Cephalotes atratus

Solenopsis geminata (Fabricius, 1804)

Membracidae

\begin{tabular}{|c|c|c|c|c|c|}
\hline \multirow{9}{*}{ Anobilia sp.1 } & Azteca chartifex spiriti & & 18 & 14 & 32 \\
\hline & Crematogaster limata & & 2 & 2 & 4 \\
\hline & Crematogaster acuta & 1 & & & 1 \\
\hline & Crematogaster curvispinosa & & & 1 & 1 \\
\hline & Dolichoderus bidens & & 25 & 12 & 37 \\
\hline & Dolichoderus bispinosus & & 3 & 2 & 5 \\
\hline & Ectatomma tuberculatum & 1 & 8 & 2 & 11 \\
\hline & Linepithema neotropicum & & 2 & 1 & 3 \\
\hline & Solenopsis sp.1 & & 1 & & 1 \\
\hline \multirow{4}{*}{ Anobilia sp. 2} & Cephalotes atratus & & 7 & 2 & 9 \\
\hline & Dolichoderus bidens & 2 & 5 & & 7 \\
\hline & Ectatomma edentatum & & & 1 & 1 \\
\hline & Ectatomma tuberculatum & & 1 & & 1 \\
\hline \multirow{3}{*}{ Anobilia sp.3 } & Azteca instabilis & & 4 & 2 & 6 \\
\hline & Dolichoderus bidens & & 3 & & 3 \\
\hline & Nylanderia sp.1 & & & 1 & 1 \\
\hline \multirow{2}{*}{ Anobilia sp.4 } & Azteca chartifex Forel, 1896 & & & 1 & 1 \\
\hline & Dolichoderus bidens & & 1 & & 1 \\
\hline \multirow{4}{*}{ Aphetea sp. } & Azteca chartifex spiriti & & 2 & & 2 \\
\hline & Cephalotes atratus & & & 1 & 1 \\
\hline & Dolichoderus bidens & & 2 & 5 & 7 \\
\hline & Dolichoderus lutosus (Smith, F., 1858) & & 1 & & 1 \\
\hline \multirow{5}{*}{$\begin{array}{l}\text { Bolbonota melaena } \\
\text { (German, 1835) }\end{array}$} & Azteca chartifex spiriti & & & 1 & 1 \\
\hline & Dolichoderus lutosus & & & 1 & 1 \\
\hline & Ectatomma tuberculatum & & 2 & 1 & 3 \\
\hline & Solenopsis geminata & 1 & 1 & & 2 \\
\hline & Wasmannia auropunctata & 1 & & & 1 \\
\hline Bolbonota sp. & Azteca chartifex spiriti & & 1 & 3 & 4 \\
\hline
\end{tabular}


Appendix.

\begin{tabular}{|c|c|c|c|c|c|}
\hline \multicolumn{6}{|l|}{ Appendix. } \\
\hline Family/Hemipteran species & Ant species & Flower & Pod & Leaf flush & Total \\
\hline \multirow{4}{*}{ Bolbonota sp. } & Cephalotes atratus & & & 1 & 1 \\
\hline & Dolichoderus bidens & & & 2 & 2 \\
\hline & Ectatomma tuberculatum & 2 & 3 & & 5 \\
\hline & Solenopsis geminata & & 1 & & 1 \\
\hline Fulgoromorpha sp. & Dolichoderus bidens & & 1 & & 1 \\
\hline \multirow{2}{*}{ Horiola arcuata (Fabricius, 1803) } & Dolichoderus attelaboides (Fabricius, 1775) & & 1 & & 1 \\
\hline & Dolichoderus bispinosus & & 2 & 5 & 7 \\
\hline \multirow{17}{*}{ Horiola picta (Coquebert, 1801) } & Azteca chartifex spiriti & & 16 & 4 & 20 \\
\hline & Azteca instabilis & & 1 & & 1 \\
\hline & Camponotus cingulatus & & 1 & & 1 \\
\hline & Cephalotes atratus & & 6 & 1 & 7 \\
\hline & Crematogaster abstinens & & 1 & 1 & 2 \\
\hline & Crematogaster acuta & & 7 & & 7 \\
\hline & Crematogaster curvispinosa & 1 & & & 1 \\
\hline & Crematogaster victima & & 1 & & 1 \\
\hline & Dolichoderus bidens & & 6 & 4 & 10 \\
\hline & Dolichoderus bispinosus & & 15 & 23 & 38 \\
\hline & Dolichoderus lutosus & & 3 & 1 & 4 \\
\hline & Ectatomma tuberculatum & & 7 & 1 & 8 \\
\hline & Linepithema neotropicum & & 1 & & 1 \\
\hline & Monomorium floricola & & 1 & & 1 \\
\hline & Solenopsis geminata & & 1 & & 1 \\
\hline & Solenopsis sp.1 & & 1 & & 1 \\
\hline & Wasmannia auropunctata & & 1 & & 1 \\
\hline \multirow{13}{*}{ Membracidae sp. } & Azteca chartifex spiriti & 2 & 8 & 3 & 13 \\
\hline & Azteca instabilis & & 1 & 2 & 3 \\
\hline & Camponotus novogranadensis & & & 2 & 2 \\
\hline & Cephalotes atratus & 2 & 5 & 1 & 8 \\
\hline & Crematogaster acuta & & 1 & 1 & 2 \\
\hline & Crematogaster cunvispinosa & & & 1 & 1 \\
\hline & Crematogaster victima & & 1 & & 1 \\
\hline & Dolichoderus bidens & & & 4 & 4 \\
\hline & Dolichoderus bispinosus & & 4 & 15 & 19 \\
\hline & Dolichoderus decolatus & & & 1 & 1 \\
\hline & Dolichoderus lutosus & & 2 & & 2 \\
\hline & Ectatomma edentatum & & & 1 & 1 \\
\hline & Ectatomma tuberculatum & 4 & 3 & 5 & 12 \\
\hline
\end{tabular}


Appendix.

\begin{tabular}{|c|c|c|c|c|c|}
\hline \multicolumn{6}{|l|}{ Appendix. } \\
\hline Family/Hemipteran species & Ant species & Flower & Pod & Leaf flush & Total \\
\hline \multirow{4}{*}{ Membracidae sp. } & Monomorium floricola & & 1 & 1 & 2 \\
\hline & Odontomachus haematodus & 1 & & & 1 \\
\hline & Solenopsis geminata & 1 & & 2 & 3 \\
\hline & Wasmannia auropunctata & 1 & & & 1 \\
\hline Neotynelia nigra (Funkhouser, 1940) & Cephalotes atratus & & & 1 & 1 \\
\hline \multirow{2}{*}{ Neotynelia sp. } & Cephalotes atratus & & 1 & & 1 \\
\hline & Dolichoderus bispinosus & & & 1 & 1 \\
\hline \multirow{2}{*}{ Nipaecoccus sp. } & Crematogaster victima & & 1 & & 1 \\
\hline & Monomorium floricola & & 1 & & 1 \\
\hline \multirow{5}{*}{ Phormophora sp.1 } & Cephalotes atratus & 2 & 10 & 2 & 14 \\
\hline & Crematogaster curvispinosa & & 1 & & 1 \\
\hline & Dolichoderus bidens & & 3 & & 3 \\
\hline & Dolichoderus bispinosus & 1 & & & 1 \\
\hline & Ectatomma tuberculatum & 1 & & & 1 \\
\hline \multirow{7}{*}{ Tragopa auriculata (Oliver, 1792) } & Azteca instabilis & & 1 & & 1 \\
\hline & Cephalotes atratus & & & 1 & 1 \\
\hline & Crematogaster curvispinosa & & & 2 & 2 \\
\hline & Dolichoderus attelaboides & & 1 & & 1 \\
\hline & Dolichoderus bidens & 1 & & & 1 \\
\hline & Dolichoderus bispinosus & & 2 & 15 & 17 \\
\hline & Wasmannia auropunctata & & & 1 & 1 \\
\hline \multirow{7}{*}{ Tragopa sp.1 } & Azteca chartifex spiriti & & 4 & & 4 \\
\hline & Cephalotes atratus & & 2 & 2 & 4 \\
\hline & Crematogaster acuta & & & 1 & 1 \\
\hline & Crematogaster limata & & 1 & & 1 \\
\hline & Dolichoderus bispinosus & & 2 & 1 & 3 \\
\hline & Ectatomma tuberculatum & & & 1 & 1 \\
\hline & Wasmannia auropunctata & & & 1 & 1 \\
\hline \multirow{6}{*}{ Tragopa sp.2 } & Azteca chartifex spiriti & & & 1 & 1 \\
\hline & Crematogaster limata & & & 1 & 1 \\
\hline & Dolichoderus bidens & & 5 & 5 & 10 \\
\hline & Dolichoderus bispinosus & & 6 & & 6 \\
\hline & Ectatomma tuberculatum & & 1 & & 1 \\
\hline & Wasmannia auropunctata & & & 1 & 1 \\
\hline \multirow{3}{*}{ Tropidoscyta sp.1 } & Cephalotes atratus & & 1 & & 1 \\
\hline & Crematogaster acuta & & 2 & & 2 \\
\hline & Crematogaster curvispinosa & & 1 & & 1 \\
\hline
\end{tabular}

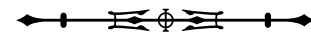


Appendix.

\begin{tabular}{|c|c|c|c|c|c|}
\hline \multicolumn{6}{|l|}{ Appendix. } \\
\hline Family/Hemipteran species & Ant species & Flower & Pod & Leaf flush & Total \\
\hline \multirow{6}{*}{ Tropidoscyta sp.1 } & Dolichoderus bidens & & 1 & & 1 \\
\hline & Ectatomma tuberculatum & & 2 & & 2 \\
\hline & Linepithema neotropicum & & & 1 & 1 \\
\hline & Solenopsis geminata & & & 1 & 1 \\
\hline & Solenopsis sp.2 & & 1 & & 1 \\
\hline & Wasmannia auropunctata & & & 1 & 1 \\
\hline \multirow{10}{*}{ Tropidoscyta sp.2 } & Azteca chartifex spiriti & & 1 & & 1 \\
\hline & Cephalotes atratus & & 2 & & 2 \\
\hline & Crematogaster acuta & & & 1 & 1 \\
\hline & Dolichoderus attelaboides & & 1 & & 1 \\
\hline & Dolichoderus bidens & 1 & 4 & 7 & 12 \\
\hline & Dolichoderus bispinosus & 1 & 2 & & 3 \\
\hline & Ectatomma edentatum & & & 1 & 1 \\
\hline & Ectatomma tuberculatum & 2 & & & 2 \\
\hline & Linepithema neotropicum & & & 1 & 1 \\
\hline & Nylanderia sp.2 & 1 & & & 1 \\
\hline \multirow{2}{*}{ Tropidoscyta sp.3 } & Azteca chartifex spiriti & & 1 & & 1 \\
\hline & Dolichoderus attelaboides & & & 1 & 1 \\
\hline \multicolumn{6}{|l|}{ Pseudococcidae } \\
\hline \multirow{6}{*}{ Dysmicoccus sp. } & Azteca chartifex spiriti & & 3 & & 3 \\
\hline & Azteca paraensis bondari Forel, 1904 & & 1 & & 1 \\
\hline & Camponotus (Myrmobrachys) sp.1 & & 1 & & 1 \\
\hline & Crematogaster limata & & & 1 & 1 \\
\hline & Pheidole sp.1 & & 1 & & 1 \\
\hline & Wasmannia auropunctata & 1 & & & 1 \\
\hline \multirow{12}{*}{ Planococcus minor (Maskell, 1897) } & Azteca chartifex spiriti & 1 & 17 & 11 & 29 \\
\hline & Azteca instabilis & 1 & 4 & 1 & 6 \\
\hline & Brachymyrmex admotus Mayr, 1887 & & & 1 & 1 \\
\hline & Camponotus crassus & & 1 & & 1 \\
\hline & Cephalotes atratus & & & 1 & 1 \\
\hline & Crematogaster abstinens & & 1 & & 1 \\
\hline & Crematogaster curvispinosa & 1 & & & 1 \\
\hline & Crematogaster abstinens & & 2 & & 2 \\
\hline & Crematogaster acuta & & 4 & 4 & 8 \\
\hline & Crematogaster carinata & & & 1 & 1 \\
\hline & Crematogaster curvispinosa & & & 1 & 1 \\
\hline & Crematogaster erecta & & & 1 & 1 \\
\hline
\end{tabular}

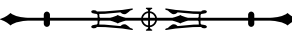


Appendix.

\begin{tabular}{|c|c|c|c|c|c|}
\hline \multicolumn{5}{|l|}{ Appendix. } & \multirow{2}{*}{$\frac{\text { (Conclusion }}{\text { Total }}$} \\
\hline Family/Hemipteran species & Ant species & Flower & Pod & Leaf flush & \\
\hline \multirow{26}{*}{ Planococcus minor (Maskell, 1897) } & Crematogaster limata & & 3 & 2 & 5 \\
\hline & Crematogaster sp.2 & & & 1 & 1 \\
\hline & Crematogaster sp.3 & & 2 & & 2 \\
\hline & Crematogaster victima & & & 2 & 2 \\
\hline & Dolichoderus bidens & & 3 & & 3 \\
\hline & Dolichoderus bispinosus & 1 & 1 & 1 & 3 \\
\hline & Dolichoderus lutosus & & 2 & & 2 \\
\hline & Ectatomma edentatum & & & 1 & 1 \\
\hline & Ectatomma tuberculatum & 3 & 13 & 3 & 19 \\
\hline & Linepithema neotropicum & & 3 & 1 & 4 \\
\hline & Monomorium floricola & & 4 & 4 & 8 \\
\hline & Nylanderia sp.1 & 1 & & & 1 \\
\hline & Odontomachus haematodus & & 1 & & 1 \\
\hline & Pheidole ambigua Wilson, 2003 & & & 1 & 1 \\
\hline & Pheidole gr. fallax sp.1 & & 1 & & 1 \\
\hline & Pheidole gr. fallax sp.2 & & 3 & 1 & 4 \\
\hline & Pheidole midas Wilson, 2003 & & & 1 & 1 \\
\hline & Pheidole radoszkowskii Mayr, 1884 & & & 1 & 1 \\
\hline & Pheidole sp.2 & & & 1 & 1 \\
\hline & Pheidole sp.3 & & 1 & & 1 \\
\hline & Solenopsis geminata & & 12 & 10 & 22 \\
\hline & Solenopsis sp.1 & & 1 & 1 & 2 \\
\hline & Solenopsis sp.2 & & 1 & 1 & 2 \\
\hline & Tetramorium simillimum Smith, 1851 & & 1 & & 1 \\
\hline & Wasmannia auropunctata & 1 & 17 & 8 & 26 \\
\hline & Wasmannia rochai & & 2 & 3 & 5 \\
\hline \multicolumn{2}{|c|}{ Total } & 134 & 404 & 394 & 932 \\
\hline
\end{tabular}


